\title{
Bike peptides: a ride through the membrane
}

\author{
Q1 Júlia García-Pindado, ${ }^{a}$ Soledad Royo, ${ }^{a}$ Meritxell Teixidóóa* \\ and Ernest Giralt ${ }^{\mathbf{a}, \mathbf{b} * \text { (b) }}$
}

\begin{abstract}
Several natural peptides have a biaryl or biaryl ether motif in their biologically active structures. A model bicyclic pentapeptide containing a biaryl bridge has been synthesized by solid-phase peptide synthesis combining on-resin Suzuki and Miyaura cross-coupling reactions. Its biological properties in terms of permeability, stability and cytotoxicity have been studied, demonstrating the positive contribution of the biaryl bridge, excellent membrane penetration and serum stability Copyright $\odot 2017$ European Peptide Society and John Wiley \& Sons, Ltd.
\end{abstract}

Keywords: solid-phase peptide synthesis; stapled peptides; Suzuki cross-coupling; borylation; head-to-tail cyclization; PAMPA; biostability

\section{Q4 Introduction}

Natural products are the source of a wealth of bioactive molecules with particular structural features. Among them, complex cyclic peptides with a biaryl bridge motif show biologically relevant activities, such as antimicrobial, proteasome inhibition or cytotoxic [1]. Over recent years, the use of catalyzed cross-coupling reactions has been extended to solid-phase peptide synthesis (SPPS) [2-6]. In particular, the Suzuki-Miyaura reaction allows $\mathrm{C}-\mathrm{C}$ bond construction in mild conditions and in a safe environment, thereby allowing access to drug-like molecules that can mimic the natural biaryl bond used as a conformational constraint and a site for recognition of protein surfaces.

One of the most important challenges in medicinal chemistry is identifying molecules with the ability to permeate across biological barriers or to increase the transport of cargoes through them. Various examples of molecules with this capacity have been reported, including cyclic and $\mathrm{N}$-methylated polypeptides, among others [7-10]. The use of a staple motif is focused mostly on fixing a particular conformation of a peptide, for instance, the $\alpha$-helix, thereby improving the pharmacologic parameters that also trigger biological activities $[11,12]$. It has also been shown that the introduction of a staple moiety can increase cell permeability [13].

Following this prior knowledge, a biaryl bicyclic peptide has been designed, combining both features mentioned earlier (cyclization and a staple, such as a biaryl bridge), in order to explore how such a structure behaves in terms of transport across biological membranes.

\section{Materials and Methods}

Protected amino acids were supplied by Iris Biotech (Marktredwitz, Germany). Wang ${ }^{\circledR}$ resin was obtained from PCAS BioMatrix Inc. (Quebec, Canada). DIEA, DIPCDI and ninhydrin were purchased from Fluka Chemika (Buchs, Switzerland) and HOAt from GL Biochem Shangai Ltd. (Shangai, China). Solvents for SPPS, such as DMF and DCM, were purchased from SDS (Barcelona, Spain) and trifluoroacetic acid (TFA) from Scharlau (Barcelona, Spain). Other chemical reagents were acquired from Aldrich (Milwaukee, $\mathrm{WI}$ ) with the highest purity commercially available. Syringes of $20 \mathrm{ml}$ for SPPS and Eppendorf tubes were provided by Scharlau and Falcon tubes by Deltalab. PAMPA plates and system solution were supplied by pION (Woburn, MA USA), and porcine polar brain lipid extract (PBLEP) by Avantis Polar Lipids (Alabaster, AL). The basic instruments used were a lyophilizer (Virtis, Frezzmobile 25 EL), oven (Selecta, Digitronic), vortex [Merck Eurolab, MELB1719 (EU)], magnetic stirrer (IKA, RCT basic), centrifuge (Eppendorf, 5415R), GUT$B X^{T M}$ (plON Aqueous Boundary Layer Thickness @ Double-Sink ${ }^{\mathrm{TM}}$ ), pipettes (Gilson, Pipetman P2, P20, P200, P1000) and Shimadzu UV-2501 PC UV-VIS spectrophotometer. HPLC analyses were performed on a Waters Alliance 2695 with an automated injector and a photodiode array detector 2998 Waters (Waters, Milford, MA) using a SunFire ${ }^{\mathrm{TM}} \mathrm{C}_{18}$ column, $3.5 \mu \mathrm{m}, 4.6 \times 100 \mu \mathrm{mm}$, and EmpowerPro 2 software. Detection was performed at $220 \mathrm{~nm}$, and the analyses were carried out with a linear gradient $0-100 \%$ $\mathrm{CH}_{3} \mathrm{CN}\left(0.036 \%\right.$ TFA) in $\mathrm{H}_{2} \mathrm{O}(0.045 \%$ TFA) over 8 min at a flow rate of $1 \mathrm{ml} / \mathrm{min}$. Ultra performance liquid chromatography (UPLC) anal- Q5 yses were performed on a Waters Acquity with an automated injector and a photodiode array detector Waters (Waters, Milford, MA) using a BEH $C_{18}$ column, $1.7 \mu \mathrm{m}, 2.1 \times 50 \mathrm{~mm}$, and EmpowerPro 3 software. Detection was performed at $220 \mathrm{~nm}$, and the analyses were carried out with a linear gradient $0-100 \mathrm{CH}_{3} \mathrm{CN}$, UPLC grade, $(0.036 \% \mathrm{TFA})$ in $\mathrm{H}_{2} \mathrm{O}(0.045 \%$ TFA) over $2 \mathrm{~min}$ at a flow rate of $0.61 \mathrm{ml} / \mathrm{min}$. UPLC-MS analyses were performed on a Waters Acquity with an automated injector and a photodiode array detector Waters (Waters, Milford, MA) coupled to an electrospray ion source ESI-MS Micromass ZQ, using a BEH $C_{18}$ column, $1.7 \mu \mathrm{m}$,

* Correspondence to: Meritxell Teixidó and Ernest Giralt, Institute for Research in Biomedicine (IRB Barcelona), Barcelona Institute of Science and Technology (BIST), 08028 Barcelona, Spain. E-mail: meritxell.teixido@irbbarcelona.org; ernest. giralt@irbbarcelona.org

a Institute for Research in Biomedicine (IRB Barcelona), Barcelona Institute of Q2 Science and Technology (BIST), 08028, Barcelona, Spain

b Department of Organic Chemistry, University of Barcelona, 08028, Barcelona, Spain 
$2.1 \times 50 \mathrm{~mm}$, and MassLynx 4.1 software. The instrument was operated in the positive ESI (+) ion mode. Detection was performed at $220 \mathrm{~nm}$, and the analyses were carried out with a linear gradient $0-100 \mathrm{CH}_{3} \mathrm{CN}$, UPLC grade, $\left(0.07 \%\right.$ formic acid) in $\mathrm{H}_{2} \mathrm{O}(0.1 \%$ formic acid) over $2 \mathrm{~min}$ at a flow rate of $0.61 \mathrm{ml} / \mathrm{min}$. Samples were introduced, in a volume (1-10 $\mu \mathrm{l})$ whose absorbance was between $0.2-$ 0.4 , into the mass spectrometer ion source directly through a UPLC autosampler.

High performance liquid chromatography purification was performed in a Waters system with 2545 binary gradient module, a 2767 manager collector, and a 2998 photodiode array detector with MassLynx 4.1 software. The column used was a Sunfire ${ }^{\mathrm{TM}} \mathrm{C}_{18}, 3.5 \mu \mathrm{m}$, $10 \times 150 \mathrm{~mm}, 100 \AA$ from Waters. The solvents were prepared as $\mathrm{CH}_{3} \mathrm{CN}\left(0.1 \%\right.$ TFA) and $\mathrm{H}_{2} \mathrm{O}(0.1 \%$ TFA). The flow rate was $10 \mathrm{ml} / \mathrm{min}$. HPLC analyses were performed to validate the correct purification of the peptide. Purity and identity was assessed by analytical UPLC-MS. Mass spectrometry characterization of all the peptides was carried out using a MALDI-TOF Applied Biosystem 4700. $1 \mu \mathrm{l}$ of the peptide in a solution with a concentration between $0.5-2 \mathrm{mg} / \mathrm{ml}$ was mixed with $1 \mu \mathrm{l}$ of $\alpha$-ciano-4-hydroxycinnamic acid $(A C H)$ matrix and then seeded on the MALDI plate and airdried. For the matrix, $10 \mathrm{mg} / \mathrm{ml}$ solution of $A C H$ was prepared in $\mathrm{CH}_{3} \mathrm{CN} / \mathrm{H}_{2} \mathrm{O} 1: 1(\mathrm{v} / \mathrm{v})$ with $0.1 \%$ TFA.

\section{General Method for Solid-Phase Peptide Synthesis}

Solid-phase peptide syntheses were performed at different scales between 100 and 500 mols. L-amino acids were used except for D-proline. Peptide elongations were carried out in 20-ml polypropylene syringes, each fitted with a polypropylene porous disk. Solvents and soluble reagents were removed by filtration. Washings between steps were performed with DMF $(3 \times 30 \mathrm{~s}), \mathrm{MeOH}$ $(3 \times 30 \mathrm{~s})$ and DCM $(3 \times 30 \mathrm{~s})$ using $10 \mathrm{ml}$ of solvent $/ \mathrm{g}$ resin each time. During couplings, the resin was stirred using an orbital shaker.

\section{Solid-Phase Miyaura Borylation Adapted from Afonso et al. [2]}

The resin was transferred to a glass vial and treated with bis(pinacolato)diboron $\left(\mathrm{B}_{2} \mathrm{Pin}_{2}\right)$ (4 equiv.), $\left.\mathrm{PdCl}_{2}\right)\left(0.18\right.$ equiv.), $1,1^{\prime}$ bis(diphenylphosphanyl)ferrocene (dppf) (0.09 equiv.) and KOAC ( 6 equiv.) in DMSO. The mixture was then heated at $85^{\circ} \mathrm{C}$ between 24 and $36 \mathrm{~h}$.

The resin was then filtered and washed with $D M F, D M F / H_{2} \mathrm{O}$, $\mathrm{MeOH}$ and DCM. An aliquot of the resulting borono resin was Q6 cleaved with $95 \%$ TFA/2.5\% $\mathrm{H}_{2} \mathrm{O} / 2.5 \%$ TIS for $1 \mathrm{~h}$. Following TFA evaporation, the crude peptide was dissolved in $\mathrm{H}_{2} \mathrm{O}: \mathrm{CH}_{3} \mathrm{CN} 1$ : 1 and then analyzed by HPLC and characterized by MS.

\section{Solid-Phase Suzuki Reaction Adapted from Afonso et al. [2] and Doan et al. [5]}

The resin was transferred to a glass vial and treated with $\mathrm{Cs}_{2} \mathrm{CO}_{3}(3$ equiv.) and $\mathrm{Pd}\left(\mathrm{PPh}_{3}\right)_{4}(0.1$ equiv.) in DMF. The mixture was stirred and heated at $65^{\circ} \mathrm{C}$ for $48 \mathrm{~h}$. The resin was then filtered and washed with DMF, MeOH and DCM. After the Suzuki reaction, the peptides were cleaved from the resin.

\section{Purification of the Crude Peptides}

In order to remove remains of palladium (from the Suzuki-Miyaura and borylation reactions), a Porapak ${ }^{\mathrm{T} M} \mathrm{RP}$ cartridge was required as an intermediate purification step prior to the head-to-tail cyclization of the compounds already bearing the biaryl bridge.
First, the column was washed with $\mathrm{MeOH}$ (two volumes) and equilibrated with $\mathrm{H}_{2} \mathrm{O}$ (one volume). After the column had dried, the sample was charged in less than $1.5 \mathrm{ml}$ methanol or $\mathrm{CH}_{3} \mathrm{CN}$ / $\mathrm{H}_{2} \mathrm{O} 1$ : 1 . The gradient started with $100 \%$ water, followed by a step by step increasing of $5 \%$. Manual pressure was applied to achieve a constant flux and facilitate elution.

Samples of the fractions were injected in the HPLC and HPLC-MS apparatuses in order to detect the product. Those fractions containing the peptide were collected and lyophilized. The flow rate and the size of the Porapak column were selected taking into account the amount of crude peptide to be purified.

Final HPLC-semipreparative purification was carried out.

\section{Head-to-Tail Cyclization in Solution}

After cleavage from the resin and Porapak ${ }^{\mathrm{TM}}$ purification, linear or linear stapled peptides were treated with PyBOP (2 equiv.), HOAt (1 equiv.), DIEA (6 equiv.) in DCM/ 1\% DMF (final concentration $1 \mathrm{~mm}$ ) at room temperature for 24-48 $\mathrm{h}$.

A final purification step by RP-HPLC on a $C_{18}$ column was required to obtain the pure cyclic peptides.

\section{Amino Acid Derivatization pNZ-(4I)-Phe-OH [14]}

The amino acid was prepared from $2 \mathrm{~g}(6.88 \mathrm{mmol})$ of $\mathrm{H}-(4 \mathrm{l}) \mathrm{Phe}-\mathrm{OH}$. p-Nitrobenzyl chloroformate (1 equiv.) was dissolved in dioxane (3 ml). Sodium azide (1.2 equiv.), previously dissolved in water $(2 \mathrm{ml})$, was added to this solution. This mixture was vigorously stirred at room temperature for $3 \mathrm{~h}$. The amino acid dissolved in dioxane $(16 \mathrm{ml})$ and $2 \%$ aq. $\mathrm{NaHCO}_{3}(16 \mathrm{ml})$ was then introduced dropwise. The mixture was allowed to react for $24 \mathrm{~h}$ at room temperature. The $\mathrm{pH}$ was kept at 9-10 and readjusted when needed. Completion of the reaction was monitored by thin layer chromatography (TLC).

The crude product was separated in 50\% $\mathrm{H}_{2} \mathrm{O} / 50 \%$ MTBE Q7 $(100 \mathrm{ml})$, and the aqueous phase was extracted with MTBE $(2 \times 50 \mathrm{ml})$. The $\mathrm{pH}$ was adjusted to 4 with aqueous $\mathrm{HCl} 12 \mathrm{~N}$. The product precipitated as a white solid. Finally, it was filtered, washed, resuspended in water and lyophilized.

\section{Loading of the First Amino Acid onto Wang Resin}

The peptides were synthesized manually on solid-phase using standard Fmoc/tBu chemistry. Wang resin (1.42 mmol/g) was used as support. Coupling of the first amino acid Fmoc-D-Pro-OH (8 equiv.) was performed using DIPCDI (4 equiv.) in 90\% DCM/10\% DMF and Q8 DMAP ( 0.8 equiv.) at room temperature overnight. The solution was filtered, and the resin was washed with DMF, DCM and $\mathrm{MeOH}$ several times. The Fmoc group was removed by treatment with $20 \%$ piperidine solution in DMF $(1 \times 5,1 \times 10$ and $1 \times 15 \mathrm{~min})$, and the loading of the resin was quantified by measuring the absorbance of the filtrate at $290 \mathrm{~nm}(\varepsilon=5900)$. The capping of the remaining reactive positions of the resin was carried out with acetic anhydride (20 equiv.) and DIEA (20 equiv.) in DMF at room temperature for $30 \mathrm{~min}$. The resin was washed again with DMF, DCM and $\mathrm{MeOH}$.

\section{Loading of the First Amino Acid onto Chlorotrityl Resin}

The peptides were synthesized manually on solid-phase using Fmoc standard chemistry. 2-CTC resin was used as support $(1.57 \mathrm{mmol} / \mathrm{g})$, and the coupling of the first amino acid Fmoc-DPro-OH (1 equiv.) was performed with DIEA (3 equiv.) in 15\% DMF and $85 \%$ DCM at room temperature for $20 \mathrm{~min}$. An extra excess 
of DIEA ( 3 equiv.) was then added, and the mixture was stirred and allowed to react for $90 \mathrm{~min}$. At this point, $0.8 \mathrm{ml} / \mathrm{g}$ resin $\mathrm{MeOH}$ was added, and the reaction was maintained for another $15 \mathrm{~min}$. When the time was over, the solution was filtered, and the resin was washed with DMF and DCM several times. Loading was determined as for the Wang resin.

\section{Identification Tests}

After each reaction, the Kaiser test [15] was used to identify primary amines on the $\mathrm{N}$-terminus of the elongating peptide on the solid support. The chloranil test [16] was used to identify secondary amines.

\section{Cleavage Conditions}

Peptides were cleaved from the Wang resin using a mixture of $95 \%$ TFA, $2.5 \% \mathrm{H}_{2} \mathrm{O}$ and $2.5 \%$ TIS. The peptides were stirred for $90 \mathrm{~min}$ with the cocktail. The compounds were then filtrated and washed with DCM. After reducing the volume under a nitrogen flux, they were resolved with $\mathrm{CH}_{3} \mathrm{CN}: \mathrm{H}_{2} \mathrm{O} 1: 1$ and lyophilized.

Regarding the sequences prepared with 2-chlorotrityl resin, cleavage was performed with 50\% TFA, 45\% DCM and 5\% $\mathrm{H}_{2} \mathrm{O}$.

\section{Synthesis and Characterization of the Peptides}

In the manuscript, we follow for brevity the nomenclature described in [17] cyclo(Lys-(4\&)Phe-Lys-(4\&)Phe-D-Pro)

The peptide was prepared starting from Fmoc-D-Pro-Wang resin. The Fmoc group was removed with $20 \%$ piperidine in DMF $(1 \times 5 \mathrm{~min}, 1 \times 15 \mathrm{~min})$. The second amino acid was introduced as $p$ NZ-(4I)Phe-OH (3 equiv.) and coupled to DIPCDI (3 equiv.) and HOAt (3 equiv.) in DMF at room temperature for $90 \mathrm{~min}$. Completion of the coupling was checked by the chloranil test. $p \mathrm{NZ}$ was then removed with a solution of $6 \mathrm{M} \mathrm{SnCl}_{2}$ and $1.6 \mathrm{~mm}$ $\mathrm{HCl} /$ dioxane $(3 \times 30 \mathrm{~min})$. The resin was washed with $\mathrm{DMF}$, $\mathrm{DMF} / \mathrm{H}_{2} \mathrm{O}, \mathrm{H}_{2} \mathrm{O} / \mathrm{THF}, \mathrm{THF}, \mathrm{MeOH}$ and DCM ( $3 \times$ each). Trt-Lys(Fmoc)-OH was coupled to PyBOP (3 equiv.) and DIEA (6 equiv.) in DMF at room temperature for $1 \mathrm{~h}$. After Fmoc removal, $p \mathrm{NZ}$ was introduced using $p \mathrm{NZCl}$ ( 3 equiv.) and DIEA (30 equiv.) in DMF at room temperature $(2 \times 45 \mathrm{~min})$. At tripeptide level, Miyaura borylation was performed following the general method for this reaction on-resin. The Trt group was then removed with $2 \%$ TFA $/ 2 \%$ $\mathrm{H}_{2} \mathrm{O} / 96 \%$ DCM $(3 \times 5$ min, $1 \times 20 \mathrm{~min})$. Between the treatments, the resin was washed twice with DCM and, after the last one, also with a solution of 5\% DIEA/95\% DCM. Fmoc-(4I)-Phe-OH (3 equiv.) was introduced with DIPCDI (3 equiv.) and oxyme (3 equiv.) in DCM/DMF. Again, deprotection of the Fmoc group preceded the coupling of the last amino acid Boc-Lys( $p N Z)-O H$ (3 equiv.), which was activated with TBTU ( 3 equiv.) and DIEA ( 6 equiv.). The Suzuki reaction was performed following the general method. Cleavage from the resin was then carried out with a mixture of $50 \%$ TFA/45\% DCM/5\% $\mathrm{H}_{2} \mathrm{O}$ under stirring for $1 \mathrm{~h}$ at room temperature. After TFA evaporation, the crude product was dissolved in $50 \%$ $\mathrm{H}_{2} \mathrm{O} / 50 \% \mathrm{CH}_{3} \mathrm{CN}$ and lyophilized. Palladium was then removed by elution through a Porapak ${ }^{\mathrm{TM}} \mathrm{RP}$ cartridge with increasing amounts of $\mathrm{CH}_{3} \mathrm{CN}$ in $\mathrm{H}_{2} \mathrm{O}$. The fractions containing the product, even when not completely pure, were pooled and lyophilized. To finish the synthesis, the peptide was cyclized using the general method, and next, $p N Z$ in lysines side chains was removed by means of $\mathrm{Na}_{2} \mathrm{~S}_{2} \mathrm{O}_{4}$ (8 equiv.) and a mixture of equal parts of $\mathrm{H}_{2} \mathrm{O}, \mathrm{CH}_{3} \mathrm{CN}$ and EtOH [18]. After $24 \mathrm{~h}$, the reagents were added again, and at $48 \mathrm{~h}$, the reaction was completed. The solvent was then evaporated, and the crude peptide was dissolved in $\mathrm{CH}_{3} \mathrm{CN}: \mathrm{H}_{2} \mathrm{O} 1: 1$, lyophilized, analyzed by HPLC and characterized by MS. This crude product was purified by HPLC, and the fractions were lyophilized again.

High-performance liquid chromatography $\mathrm{t}_{\mathrm{R}}\left(\mathrm{G} 0-100 \% \mathrm{CH}_{3} \mathrm{CN} /\right.$ $\mathrm{H}_{2} \mathrm{O}$ in 8 min): 8.0 min; UPLC $\mathrm{t}_{\mathrm{R}}\left(\mathrm{G} 0-100 \% \mathrm{CH}_{3} \mathrm{CN} / \mathrm{H}_{2} \mathrm{O}\right.$ in $\left.2 \mathrm{~min}\right):$ $1.8 \mathrm{~min}$; UPLC-MS $\mathrm{t}_{\mathrm{R}}\left(\mathrm{G} 0-100 \% \mathrm{CH}_{3} \mathrm{CN} / \mathrm{H}_{2} \mathrm{O}\right.$ in $2 \mathrm{~min}$ ): $1.8 \mathrm{~min}$, $\left[\mathrm{M}+\mathrm{H}^{+}\right]_{\text {expected }}=645.36,\left[\mathrm{M}+\mathrm{H}^{+}\right]_{\text {found }}=645.44$, HRMS (ESI): calcd. For $\mathrm{C}_{35} \mathrm{H}_{48} \mathrm{~N}_{7} \mathrm{O}_{5}$ 645.3533; $\left[\mathrm{M}+\mathrm{H}^{+}\right]_{\text {found }}=645.3536$; yield (synthesis + purification): $1 \%$.

\section{H-Lys-Phe-Lys-Phe-D-Pro-OH}

This peptide was prepared from Fmoc-D-Pro-CTC resin (1 equiv. $=0.58 \mathrm{mmol}$ ). Fmoc-Phe-OH and Fmoc-Lys $(\mathrm{Boc})-\mathrm{OH}$ residues (3 equiv.) were attached using DIPCDI (3 equiv.) and HOAt (3 equiv.) as coupling agents. Cleavage of the peptidyl sequence provided the desired peptide.

High-performance liquid chromatography $t_{R}\left(G 0-100 \% \mathrm{CH}_{3} \mathrm{CN} /\right.$ $\mathrm{H}_{2} \mathrm{O}$ in 8 min): $4.1 \mathrm{~min}$; UPLC $\mathrm{t}_{\mathrm{R}}\left(\mathrm{G} \mathrm{O}-100 \% \mathrm{CH}_{3} \mathrm{CN} / \mathrm{H}_{2} \mathrm{O}\right.$ in $2 \mathrm{~min}$ ): $1.3 \mathrm{~min}$; UPLC-MS $t_{\mathrm{R}}\left(\mathrm{G} 0-100 \% \mathrm{CH}_{3} \mathrm{CN} / \mathrm{H}_{2} \mathrm{O}\right.$ in $2 \mathrm{~min}$ ): $1.3 \mathrm{~min}$, $\left[\mathrm{M}+\mathrm{H}^{+}\right]_{\text {expected }}=666.39,\left[\mathrm{M}+\mathrm{H}^{+}\right]_{\text {found }}=666.29, \mathrm{HRMS}$ (ESI): calcd. For $\mathrm{C}_{35} \mathrm{H}_{52} \mathrm{~N}_{7} \mathrm{O}_{6} 666.3974 ;\left[\mathrm{M}+\mathrm{H}^{+}\right]_{\text {found }}=666.3970$; yield (synthesis + purification): $44 \%$.

\section{Cyclo(Lys-Phe-Lys-Phe-D-Pro)}

This peptide was prepared by cyclization of previously synthesized linear peptide (H-Lys-Phe-Lys-Phe-D-Pro-OH) following the general cyclization method. Cleavage conditions in this synthesis involved $2 \%$ TFA/98\% DCM to maintain Boc protecting groups in lysine side chains. Boc removal in solution was achieved by adding a $75 \%$ TFA/25\% DCM solution to the peptide. The mixture was stirred at room temperature for $4 \mathrm{~h}$. The reaction was monitored by TLC (50\% AcOEt/ 50\% DCM) using the ninhydrin staining solution. The solvent was evaporated, and the crude product was dissolved in $\mathrm{CH}_{3} \mathrm{CN}: \mathrm{H}_{2} \mathrm{O} 1: 1$, lyophilized, analyzed by HPLC and characterized by MS.

High-performance liquid chromatography $t_{R}\left(G 0-100 \% \mathrm{CH}_{3} \mathrm{CN}\right.$ / $\mathrm{H}_{2} \mathrm{O}$ in 8 min): 6.0 min; UPLC $t_{R}\left(G 0-100 \% \mathrm{CH}_{3} \mathrm{CN} / \mathrm{H}_{2} \mathrm{O}\right.$ in $\left.2 \mathrm{~min}\right)$ : $1.4 \mathrm{~min}$; UPLC-MS $t_{\mathrm{R}}$ (G $0-100 \% \mathrm{CH}_{3} \mathrm{CN} / \mathrm{H}_{2} \mathrm{O}$ in $2 \mathrm{~min}$ ): $1.4 \mathrm{~min}$, $\left[\mathrm{M}+\mathrm{H}^{+}\right]_{\text {expected }}=648.38,\left[\mathrm{M}+\mathrm{H}^{+}\right]_{\text {found }}=649.23, \mathrm{HRMS}$ (ESI): calcd. For $\mathrm{C}_{35} \mathrm{H}_{50} \mathrm{~N}_{7} \mathrm{O}_{5}$ 648.3868; $\left[\mathrm{M}+\mathrm{H}^{+}\right]_{\text {found }}=648.3878$; yield (synthesis + purification): $15 \%$.

\section{H-Lys-(4\&)Phe-Lys-(4\&)Phe-D-Pro-OH}

The peptide was synthesized from Fmoc-D-Pro-CTC resin ( $1 \mathrm{eq}=0.53 \mathrm{mmol}$ ). The same procedure as for the bicyclic peptide was used to prepare this sequence. The Trt-Lys(Fmoc)-OH residue was required as in the bicyclic peptide synthesis. In this particular sequence, Fmoc was exchanged for Boc to facilitate removal of these protecting groups concomitantly in the final cleavage. Cleavage of the sequence provided the desired unprotected peptide.

High-performance liquid chromatography $\mathrm{t}_{\mathrm{R}}\left(\mathrm{G} 0-100 \% \mathrm{CH}_{3} \mathrm{CN}\right.$ / $\mathrm{H}_{2} \mathrm{O}$ in 8 min): 5.3 min; UPLC $t_{R}\left(\mathrm{G} \mathrm{0-100 \%} \mathrm{CH}_{3} \mathrm{CN} / \mathrm{H}_{2} \mathrm{O}\right.$ in $2 \mathrm{~min}$ ): $1.3 \mathrm{~min}$; UPLC-MS $t_{R}\left(\mathrm{G} 0-100 \% \mathrm{CH}_{3} \mathrm{CN} / \mathrm{H}_{2} \mathrm{O}\right.$ in $2 \mathrm{~min}$ ): $1.3 \mathrm{~min}$, $\left[\mathrm{M}+\mathrm{H}^{+}\right]_{\text {expected }}=664.37,\left[\mathrm{M}+\mathrm{H}^{+}\right]_{\text {found }}=664.49$, HRMS (ESI): calcd. For $\mathrm{C}_{35} \mathrm{H}_{50} \mathrm{~N}_{7} \mathrm{O}_{6} 664.3817 ;\left[\mathrm{M}+\mathrm{H}^{+}\right]_{\text {found }}=664.3818$; yield (synthesis + purification): $3 \%$. 


\section{Parallel Artificial Membrane Permeability Assay}

The parallel artificial membrane permeability assay (PAMPA) was used to measure the capacity of the peptides to cross the bloodbrain barrier (BBB) by passive diffusion. The effective permeability $\left(\mathrm{P}_{\mathrm{e}}\right)$ of the compounds was determined at an initial concentration of $200 \mu \mathrm{m}$. The buffer solution was prepared from a commercially concentrated one, supplied by pION. Following the manufacturer's instructions, system solution was adjusted to $\mathrm{pH} 7.4$ using a $0.5 \mathrm{M}$ $\mathrm{NaOH}$ solution. The peptides were dissolved in a mixture of buffer solution with $20 \%$ of 1-propanol used as cosolvent. The PAMPA sandwich was separated, and the donor well was filled with $195 \mu \mathrm{l}$ of the compound solution of interest. A magnetic stirrer was placed in each well. The acceptor plate was put into the donor plate, ensuring that the underside of the membrane was in contact with the buffer. Then, $4 \mu$ l of a mixture of phospholipids from a porcine polar brain extract $(20 \mathrm{mg} / \mathrm{ml})$ in dodecane (composition: 12.6\% phosphatidylcholine (PC), 33.1\% phosphatidylethanolamine (PE), 18.5\% phosphatidylserine (PS), 4.1\% phosphatidylinositol (PI), $0.8 \%$ phosphatidic acid and $30.9 \%$ of other compounds) was added to the filter of each well, followed by $200 \mu$ l of buffer solution. The plate was then covered and incubated at room temperature in a saturated humidity atmosphere for $4 \mathrm{~h}$ under orbital agitation at $25 \mu \mathrm{m}$ of unstirred water layer. After this period, $165 \mu \mathrm{l} /$ well of the solution from the donor and acceptor plates was transferred to the HPLC vials, except for the bicyclic compound, for which all the fractions were pooled. One-hundred microliter of each linear, stapled and cyclic acceptor samples and $80 \mu \mathrm{l}$ of the bicyclic acceptor were injected into the HPLC apparatus. Transport was also confirmed by HPLC-MS, which indicated that the integrity of the peptides was preserved. Regarding the donor and initial time samples, the linear compound was injected at $1 \mu \mathrm{l}$, the linear stapled peptide at $20 \mu \mathrm{l}$, the head-to-tail cyclic peptide at $10 \mu \mathrm{l}$ and the bicyclic peptide at $5 \mu$ l.The bicyclic acceptor was injected again at 1 and $5 \mu$ l owing to the initial large absorbance obtained.

The effective permeability after $4 \mathrm{~h}$ was calculated using Eqn (1) and the percentage of transport using Eqn (2).

$$
\begin{gathered}
T(\%)=\frac{C_{A}(t)}{C_{D}\left(t_{0}\right)} \cdot 100 \\
P_{e}=\frac{-218.3}{t} \cdot \log \left[1-\frac{2 \cdot C_{A}(t)}{C_{D}\left(t_{0}\right)}\right] \cdot 10^{-6} \mathrm{~cm} / \mathrm{s}
\end{gathered}
$$

where $t$ is time $(h), C_{A}(t)$ is the peptide concentration in the acceptor well at time $t$ and $C_{D}\left(t_{0}\right)$ is the peptide concentration in the donor well at $0 \mathrm{~h}$. Membrane retention (\%R) was calculated from the difference between the total starting amount of peptide and the amount of peptide in the donor and acceptor wells at the end of the assay after $4 \mathrm{~h}$.

\section{Peptide Stability in Human Serum}

Q9 Peptides at a final concentration of $3 \mathrm{~mm}$ were dissolved in HBSS and incubated at $37{ }^{\circ} \mathrm{C}$ in the presence of $90 \%$ human serum for $24 \mathrm{~h}$. At different incubation times (30 min, 1, 3, 6, 10, 12 and $24 \mathrm{~h}$ ), $50 \mu \mathrm{l}$ aliquots were treated with $200 \mu \mathrm{l}$ of methanol to precipitate serum proteins. After $30 \mathrm{~min}$ of centrifugation at $4{ }^{\circ} \mathrm{C}$, the supernatant was filtered and then analyzed by RP-HPLC to calculate the percentage of intact peptide in the sample.

\section{Cytotoxicity, MTT assay.}

Twenty-four hours before starting the assay, 3500 HeLa cells were seeded in 96-well plates. After this period, cells with peptides at 200 and $500 \mu \mathrm{M}$ in DMEM (1 mg/ml glucose) supplemented with $10 \%$ se- Q10 rum were incubated for $24 \mathrm{~h}$. After $22 \mathrm{~h}, \mathrm{MTT}$ reagent was added to a final concentration of $0.5 \mathrm{mg} / \mathrm{ml}$. After a $4 \mathrm{~h}$ incubation, the medium was discarded, and the purple crystals of formazan were dissolved in $200 \mu$ l of DMSO. The plate was shaken for $30 \mathrm{~min}$, and absorbance was measured at $570 \mathrm{~nm}$. Cell viability was calculated by dividing the absorbance of wells treated with a given peptide by the absorbance of the untreated wells. Measurements were performed in triplicate. As a positive control, cells were incubated with $1 \%$ SDS.

\section{Results and Discussion}

\section{Design of Bike Peptides}

As a model, a pentapeptide sequence was chosen (Figure 1), as five F1 amino acid rings are formed at reasonable yields and without further difficulties, rendering molecules with sufficient rigidity conferred by the presence of the biaryl staple motif.

Because we focused on exploring the capacity of the bike peptide to cross biological barriers, the most suitable amino acids were selected for the remaining two positions on the basis of achieving equilibrium between hydrophocity and hydrophilicity in order to avoid membrane retention. Furthermore, satisfactory solubility of the molecules should be ensured, as well as the presence of positive charges, whose introduction is widely used for protein-protein interactions (PPIs) once inside the brain [19-21].

For all these reasons, the selected two remaining residues were lysines, a good building block as it favors PPIs.

\section{Synthesis and Characterization of Bike Peptides and Other Control Sequences}

Figure 2 shows the synthetic scheme followed for the synthesis of F2 the sequence cyclo(Lys-(4\&)Phe-Lys-(4\&)Phe-D-Pro). Some

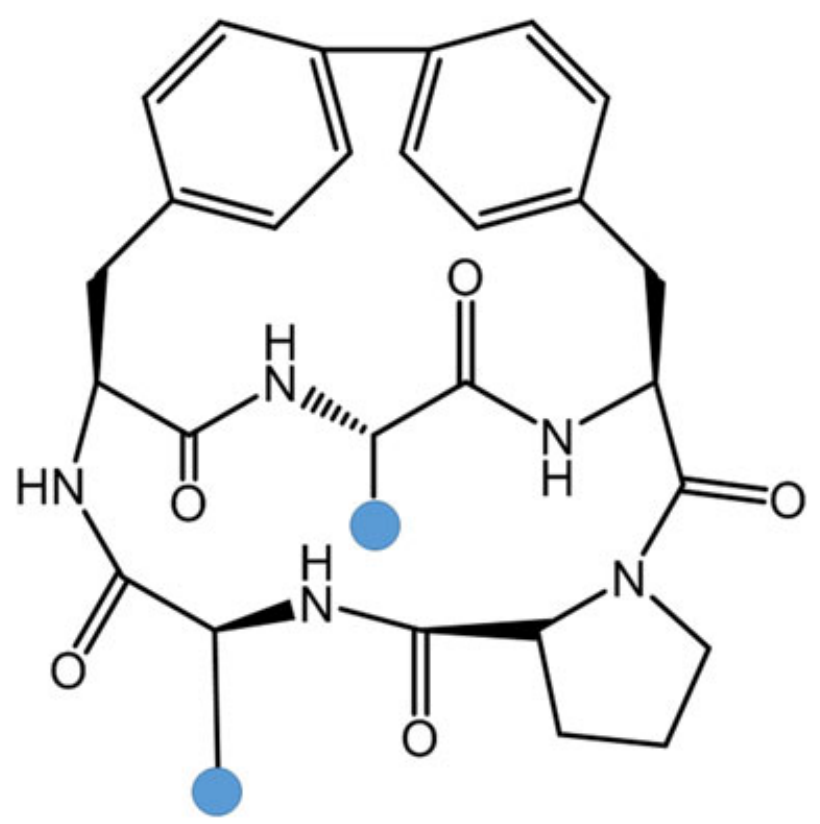

Figure 1. Structure of the general scaffold for the bicyclic peptides. 

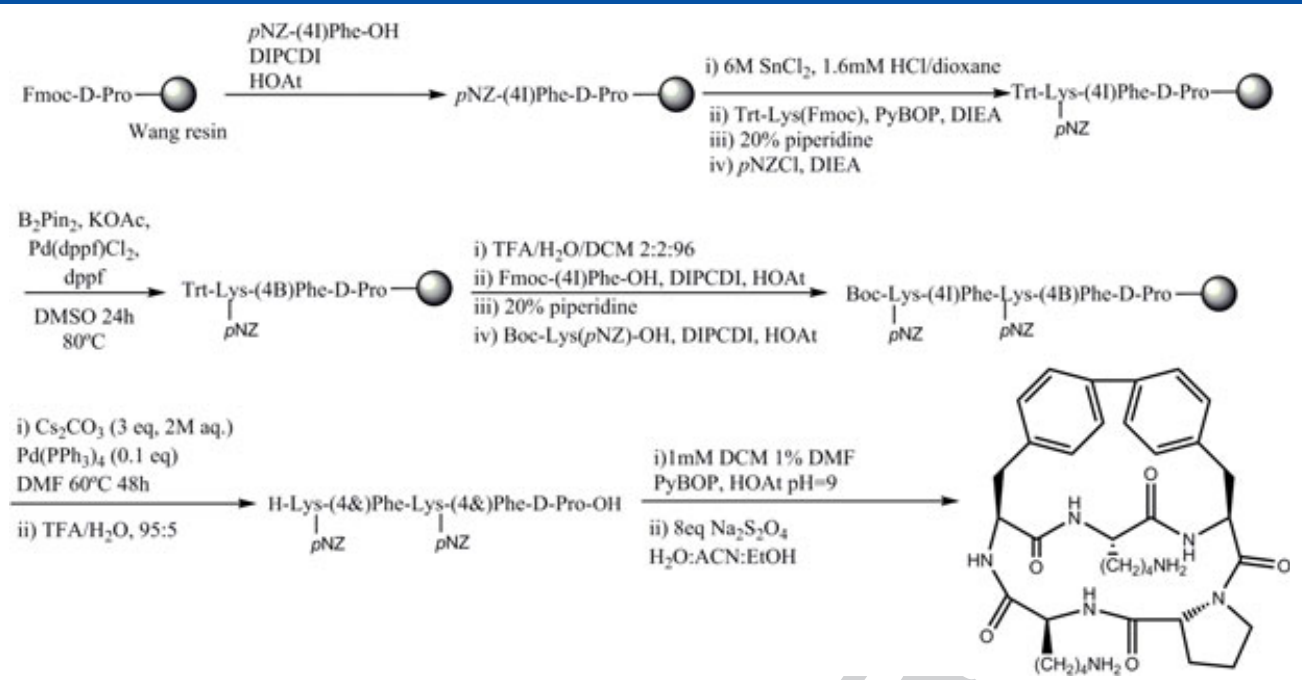

Figure 2. Solid-phase peptide synthesis cyclo(Lys-(4\&)Phe-Lys-(4\&)Phe-D-Pro).

modifications to the standard Fmoc/tBu protocols [22] were required, and the synthetic route included an on-resin borylation, an intramolecular solid-phase Suzuki-Miyaura reaction and an in solution head-to-tail cyclization.

Briefly, the peptide was synthesized on solid-phase using $\mathrm{Fmoc} / \mathrm{tBu}$ chemistry. Wang resin was chosen as the best option because it provides the linear peptide with a C-terminal carboxylic acid and is stable under the required reaction conditions [23], whereas 2-chlorotrytil resin would be labile during deprotection of the main chain protecting group after Miyaura borylation. D-Proline was selected as C-terminal amino acid on the resin in order to later favor cyclization in solution and provide extra rigidity to the overall structure of the peptide. It must be taken into account that this sequence is highly prone to diketopiperazine (DKP) formation because of the presence of proline in the C-terminus and specifically because the sequences of the first and second amino acid are L-D in terms of configuration [24]. Furthermore, Wang resin does not prevent DKP formation. Therefore, the second amino acid was introduced as a $p \mathrm{NZ}$ derivative to avoid DKP formation [14] during the $\mathrm{N}$-terminal deprotection in basic conditions. Mild coupling conditions were chosen in order to avoid side reactions. Therefore, couplings were performed with DIPCDI, even in the case of coupling onto secondary amines such as Pro. When the amino acid to be coupled was protected with Trt, phosphonium salts were used due to stronger conditions required for the coupling of this hindered amino acid derivative $[23,25]$. Another important point to take into account is the $\mathrm{pH}$ of the medium before the coupling of third amino acid. After removal of $p \mathrm{NZ}$, the medium must be neutralized because deprotection takes place in acidic conditions. Nevertheless, deprotection can be performed by in situ neutralization during the next coupling with a base like DIEA, commonly used in combination with coupling agents such as PyBOP [23,24]. Regarding the third residue, it was introduced with a Trt protecting group in the backbone and Fmoc in the side chain, which was subsequently substituted by $p N Z$. The biaryl staple was formed between two phenylalanines introduced in the sequence. For this, $p$-iodine phenylalanines were selected, performing Miyaura borylation on one of them. We decided to perform Miyaura borylation at the tripeptide level as a dipeptide is too small to be followed by HPLC-MS. In addition, borylation on the second residue could imply steric hindrance from the resin.
One of the most important aspects of designing the synthesis of these peptides was the selection of orthogonal protecting groups. Figure 3 shows all the protecting groups tested and their viability. F3 It is worth noting that there are different factors like medium conditions, reagents or resin that influence this selection. For the borylation and Suzuki reaction steps, the presence of base and catalyst reduces the number of compatible protecting groups. These groups cannot be base-labile, because the free amine is not compatible with these reactions, and it is important to avoid simultaneous deprotection. In addition, the protecting group should be compatible with an acid-labile resin, such as Wang resin. Fmoc is not stable under basic conditions, while Boc is stable under borylation but is not compatible with elongation on acid-labile resins. Also, Alloc is not stable in the presence of $\mathrm{Pd}$, which is used in the Suzuki-Miyaura reactions. Finally, Trt and $p N Z$ are both stable under borylation and compatible with some acid-labile resins such as Wang resin.

The side chain of lysines should also be protected with orthogonal protecting groups, which may be removed in solution at the end of the synthesis after head-to-tail cyclization in solution. $p N Z$ was the most suitable group as it showed orthogonality with the synthetic strategy, including stability to the cleavage conditions (95\% TFA containing cleavage cocktails) and the possibility to be removed in solution once the bicyclic peptide had been obtained.

The Suzuki reaction was performed on-resin to build the biaryl bridge between the two aromatic residues, and when it was complete, cleavage from the resin was carried out. Head-to-tail cyclization was performed under high dilution to hinder the intermolecular reaction and favor the intramolecular one, because our aim was to obtain a bicyclic peptide and prevent undesired dimerization. The last step was the in solution removal of $p N Z$ protecting groups on lysines, which was carried out in reductive conditions with $\mathrm{Na}_{2} \mathrm{~S}_{2} \mathrm{O}_{4}$ [17].

Palladium is used in small amounts as a catalyst in both borylation and the Suzuki reaction. Although the crude product obtained after cyclization will always require a final purification, the removal of palladium before performing cyclization in solution is mandatory because this compound can interfere with the reactivity of the amine.

Palladium can be removed in several ways, including through the use of chelating species [26], which attach to this metal to form a 


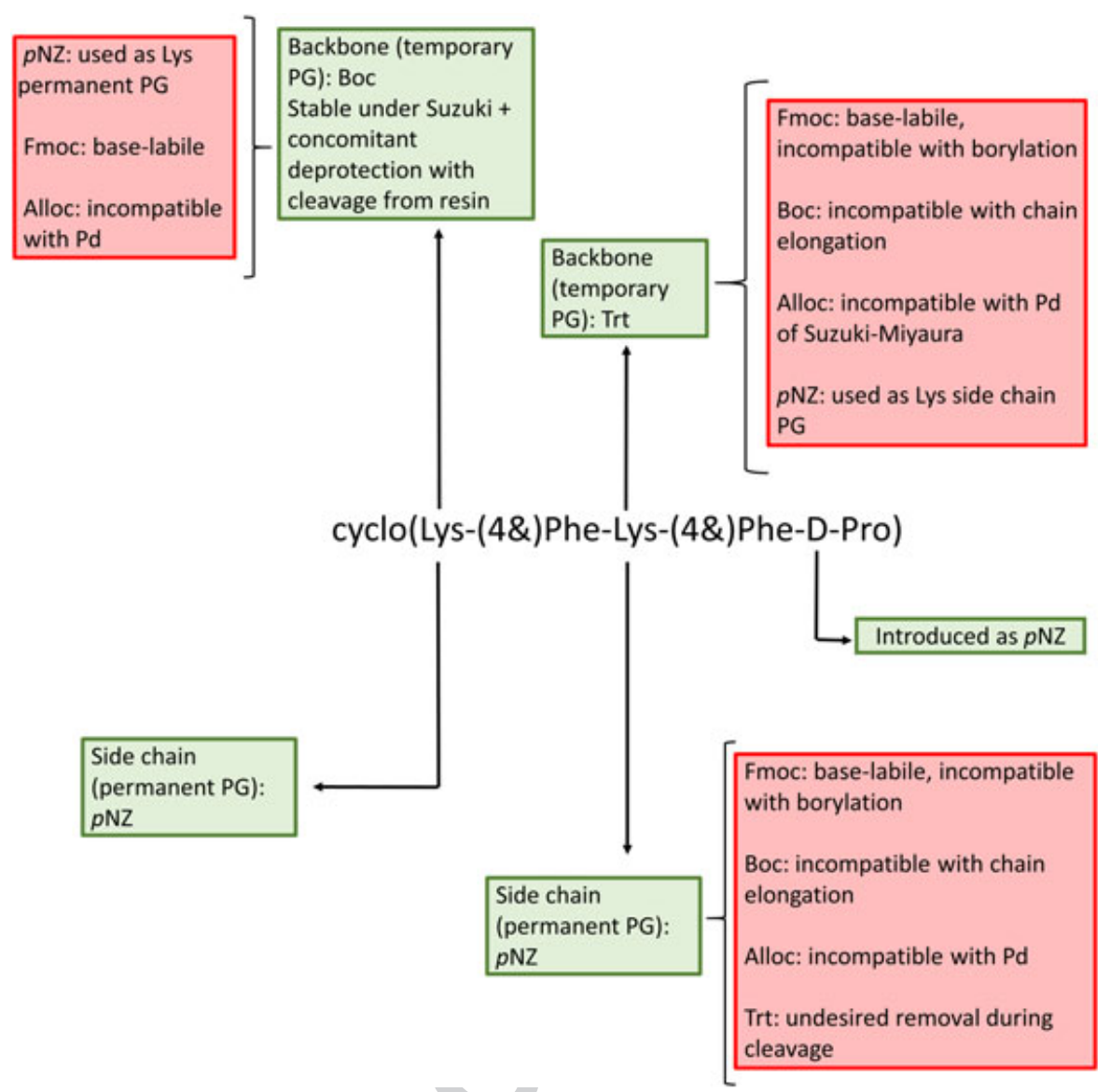

Figure 3. Protecting group (PG) scheme for the synthesis of the bicyclic peptide cyclo(Lys-(4\&)Phe-Lys-(4\&)Phe-D-Pro).

soluble complex, thereby leaving the solution free of palladium. It is also possible to treat the cleaved peptide with a scavenger resin specific for this element. However, such methods are useful only when the amount of palladium is really low, not the current case. Another option is to use a Porapak $^{\mathrm{TM}}$ reversed-phase cartridge. While this method does not provide a completely pure linear peptide, it is efficient in removing palladium and other impurities in a simple and rapid manner.

Therefore, after the Suzuki reaction and cleavage of the peptide from the resin, palladium is removed by using a Porapak ${ }^{\mathrm{TM}}$ reversedphase cartridge. The small traces of palladium that might remain in the crude product does not interfere with the cyclization and is finally removed in the last purification step, which is performed by semipreparative HPLC.

In addition to the bicyclic bike peptide, a cyclic analog with the two unmodified Phe [cyclo(Lys-Phe-Lys-Phe-D-Pro)] was synthesized. By comparison to the bicyclic peptide, the relevance of the biaryl staple motif can be studied. Furthermore, we synthesized the linear version of the peptide (H-Lys-Phe-Lys-Phe-D-Pro-OH), which also provides information related to the influence of the head-to-tail cyclization, and the linear stapled peptide (H-Lys-(4\&) Phe-Lys-(4\&)Phe-D-Pro-OH), which enables to test the effect of this staple motif alone, without including the head-to-tail cyclization

F4 constrain (Figure 4).

The linear pentapeptide was synthesized using standard Fmoc/tBu SPPS with chlorotrityl resin and concomitant cleavage and deprotection of the Boc side-chain protecting group. The head-to-tail cyclic peptide was prepared following a similar protocol using mild cleavage conditions ( $2 \%$ TFA/98\% DCM) to maintain lysine side chains protected until the cyclization in solution was finished. Once the cyclic peptide had formed, Boc removal in solution was carried out. The linear stapled peptide was prepared with the same protocol as that used for the bicyclic molecule but using Boc as lysine side-chain protecting group, which was later removed during cleavage.

\section{Permeability across Biological Barriers}

Drug targeting to the brain has gained relevance over the years owing to the number of diseases that affect the central nervous system, such as Alzheimer's and Parkinson's diseases, schizophrenia or epilepsy, among others. In this field, peptides are experiencing their golden era. Nevertheless, a limitation shared by the vast majority of potential drug candidates concerns their ability to cross the BBB $[27,28]$.

Commonly known as a shell, brain parenchyma is protected from harmful substances in circulating blood by three barriers that also modulate the entry of some particular molecules. These are the BBB, which is found in the capillaries; the blood-cerebrospinal fluid barrier, comprised by the choroid plexus epithelium, and the ependyma, which is placed at the interphase between the cerebrospinal fluid and the brain.

The BBB is a physical and enzymatic barrier formed mainly by brain capillary endothelial cells. However, other cell types, such as astrocytes, pericytes and neurons, also play a relevant role in regulating permeability of the BBB. The cells forming the BBB differ from others because they have very few endocytotic vesicles, thus limiting the amount of transcellular flux, and they form tight junctions, 

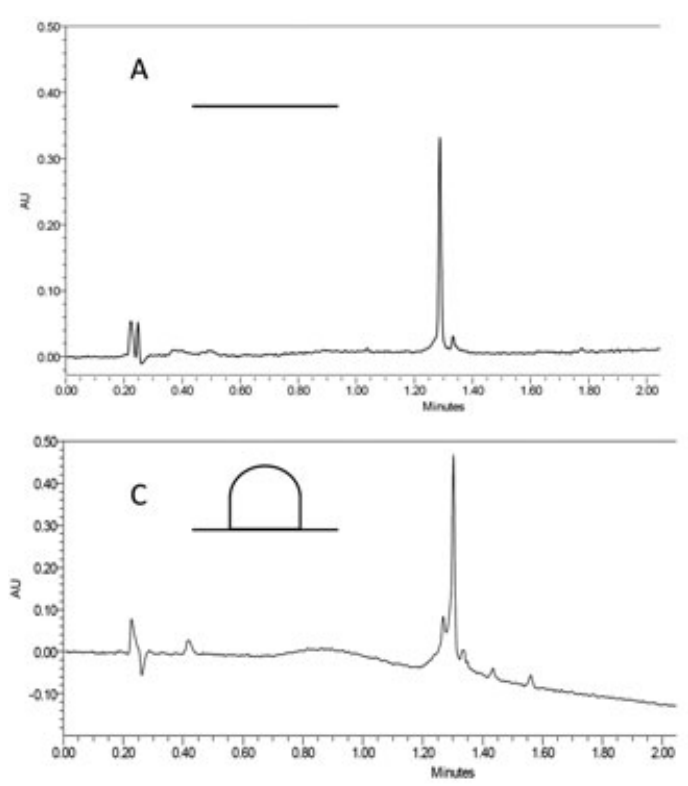
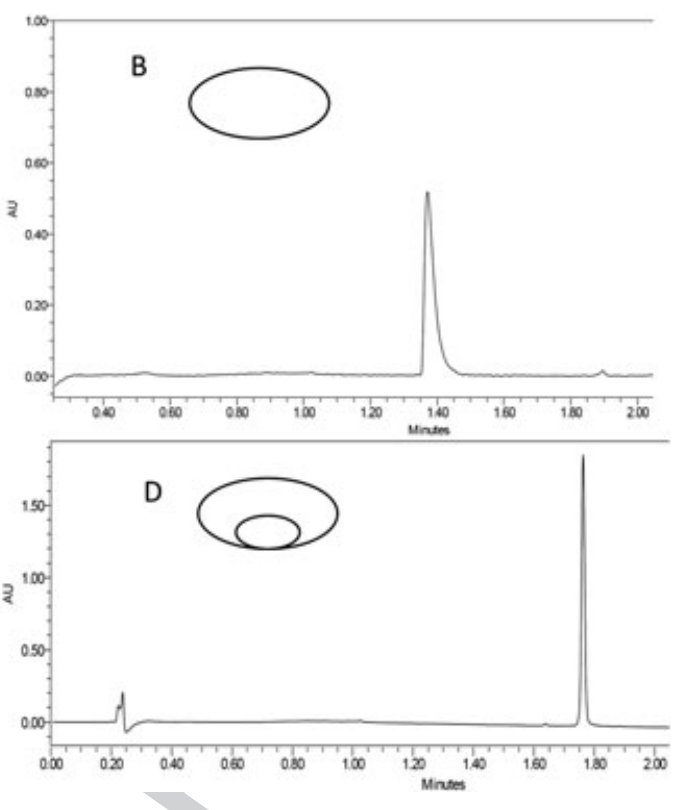

Figure 4. Ultra performance liquid chromatography chromatogram of the pure peptides in a gradient $0-100 \% \mathrm{CH}_{3} \mathrm{CN}$ in 2 min. Column $\mathrm{BEH} \mathrm{C} 18,1.7 \mu \mathrm{m}$, $2.1 \times 50 \mathrm{~mm}$. (A) linear, (B) head-to-tail cyclic, (C) linear stapled and (D) bicyclic peptides.

which are responsible for the limited paracellular diffusion and a minimal level of pinocytosis. Furthermore, efflux transporters and multidrug-resistant proteins avoid the transcytosis of some compounds. Therefore, one of the remaining existing transport mechanisms at the BBB is passive diffusion [27,29-33].

We therefore question whether the imposed rigidity conferred by a biaryl bridge could be an advantageous property of our compounds in terms of transport by passive diffusion across biological membranes such as the BBB.

In order to evaluate the permeability of our peptides, we selected the PAMPA, which requires small amounts of the compounds and is simple, fast and inexpensive. It is the gold standard method for assessing transport by passive diffusion permeation of these compounds and shows good correlation with the in vivo context. Initially, described by Kansy [34], the PAMPA is based on a 96-well plate and consists of an artificial membrane that is coated with phospholipids, mimicking the membrane of study but has no means for active or paracellular transport. We used an extract of lipids from porcine brain to mimic the BBB [35]. Propranolol, a $\beta$ adrenergic receptor blocker, was used as control. The ability of Q111 these peptides to cross the BBB is shown in Table 1.

The four compounds showed high permeability across the PAMPA membrane, all with an effective permeability higher than $1 \times 10^{-6} \mathrm{~cm} / \mathrm{s}$, which correlates to a good transport prediction in vivo [34]. Nonetheless, it is worth noting that the values obtained for the peptides displaying the biaryl motif were one order of mag-

F5 nitude higher than those lacking this staple (Figure 5), thus implying that this structural feature favors transport across the BBB by passive diffusion. Therefore, it may be concluded that a biaryl staple can be introduced to increase the permeability of linear and cyclic peptides, while cyclization itself is not as powerful as a tool in terms of increasing transport across membranes.

Low unwanted retention in the membrane was observed after calculating the mass balance for these peptides. Of note, high membrane retention is not always an indication of better transport as it could reflect that the compound is trapped in the membrane and is thus unable to reach the brain side of the barrier.
On the basis of these results, we conclude that the biaryl staple is a powerful tool that can be used to enhance the transport of linear and/or cyclic peptides by passive diffusion, thus enriching the existing chemical toolbox for this purpose. The peptidomimetics obtained in the present study show permeability values of interest that deserve further consideration.

\section{Protease Resistance of Bike Peptides}

Having explored the high potential of stapled peptides with respect to increasing passive transport, we extended the study to other properties such as protease resistance.

The high potential of peptides as therapeutic agents is sometimes reduced because of their poor resistance to proteases, which results in in vivo fragility of these molecules [36]. In this regard, further development of protease-resistant peptides is required.

Cyclic peptides typically show better stability inside the human body as their constrained structures prevents amino and carboxipeptidase degradation and makes it more difficult for endopeptidases to gain access to them and degrade the compounds. Nonetheless, there are other privileged structures whose lability is also reduced, such as $N$-methylated peptides and peptidomimetics, including non-natural residues [33-35,37-40].

Table 1. Percentage of transport $(\% T)$ and effective permeability $\left(P_{e}\right)$ in the PAMPA after $4 \mathrm{~h}$

\begin{tabular}{|c|c|c|}
\hline Compound & $\begin{array}{l}\mathrm{P}_{\mathrm{e}}\left(\times 10^{6}\right) \\
\mathrm{cm} / \mathrm{s}\end{array}$ & $\mathrm{T}(\%)(4 \mathrm{~h})$ \\
\hline Bicyclic: cyclo(Lys-(4\&)Phe-Lys-(4\&)Phe-D-Pro) & $14.3 \pm 3.3$ & $22.6 \pm 0.6$ \\
\hline $\begin{array}{l}\text { Linear stapled: H-Lys-(4\&)Phe-Lys-(4\&) } \\
\text { Phe-D-Pro-OH }\end{array}$ & $9.2 \pm 1.8$ & $16 \pm 2.6$ \\
\hline Head-to-tail cyclic: cyclo(Lys-Phe-Lys-Phe-D-Pro) & $1.4 \pm 0.1$ & $2.9 \pm 0.2$ \\
\hline Linear: H-Lys-Phe-Lys-Phe-D-Pro-OH & $1.5 \pm 0.1$ & $3.1 \pm 0.3$ \\
\hline Propranolol & $5.8 \pm 0.5$ & $18.2 \pm 0.8$ \\
\hline
\end{tabular}




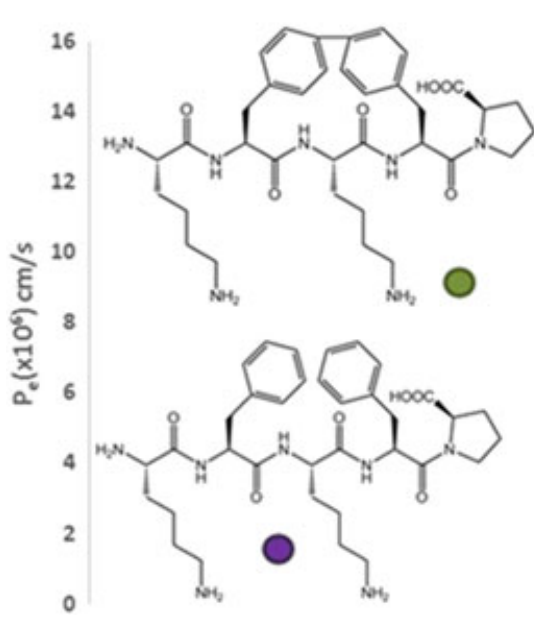

Figure 5. Effective permeability of our derivatives in the PAMPA after $4 \mathrm{~h}$.

Here, we sought to test the effect of the biaryl bridge on the biostability of these peptides. In this regard, we compared the four analogs (linear, linear stapled, head-to-tail cyclic and bicyclic versions).

We first evaluated biostability in human serum. The linear peptide was degraded in less than $30 \mathrm{~min}$, thereby demonstrating

F6 the low biostability of general linear peptides (Figure 6). The head-to-tail cyclic and the linear stapled versions of the peptides showed enhanced biostability, with half-lives close to $3 \mathrm{~h}$. Finally, the bicyclic analog was the most stable compound. Indeed, even after $24 \mathrm{~h}$ of incubation, no significant degradation was observed for this peptide.

On the basis of these results, we conclude that the introduction of the biaryl staple into a peptidic scaffold can provide compounds with increased values of permeability, as well as enhanced protease resistance - two properties of great interest for the design of novel drug candidates.

\section{Cytotoxicity of Bike Peptides}

After studying the benefits of introducing the biaryl bridge into the scaffolds, we also explored whether this motif induced extra cytotoxicity to these compounds.

The four peptide analogs were tested by the MTT assay in HeLa cells and at two concentrations ( 200 and $500 \mu \mathrm{M})$. None of the com-

T2 pounds showed significant cytotoxicity (Table 2 ).

However, at the highest concentration tested $(500 \mu \mathrm{M})$, the linear stapled peptide and the bicyclic analogs proved more cytotoxic than the linear and head-to-tail cyclic versions; nevertheless, these

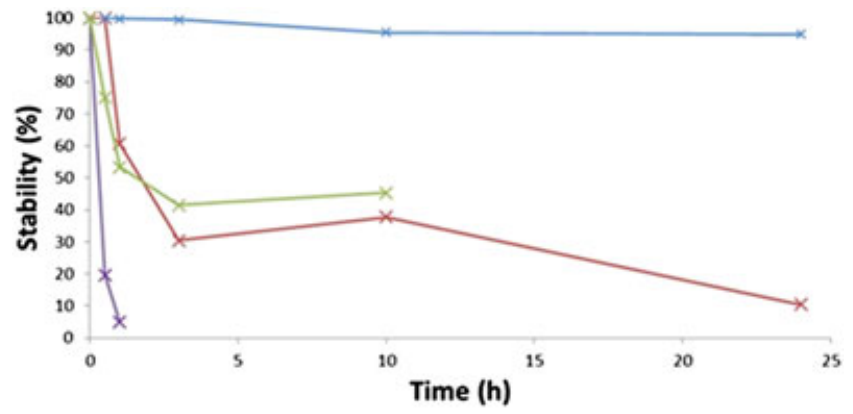

Figure 6. Biostability of the four peptides in human serum. In purple linear, in red head-to-tail cyclic, in green linear stapled and in blue bicyclic peptides.
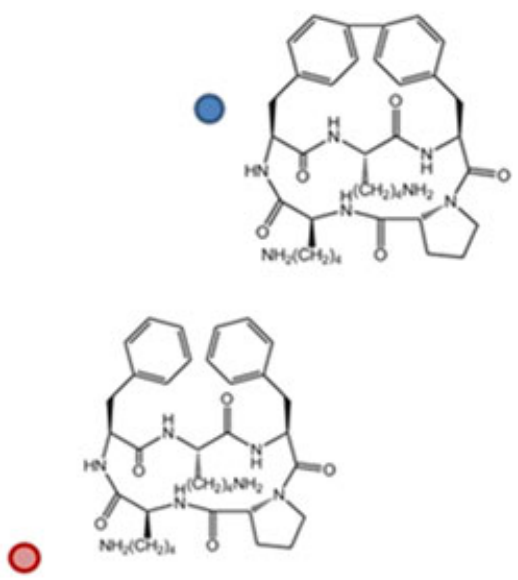

\begin{tabular}{|c|c|c|c|c|}
\hline- & Linear & Linear stapled & Head-to-tail cyclic & Bicyclic \\
\hline $200 \mu \mathrm{M}$ & 75 & 99 & 84 & 80 \\
\hline $500 \mu \mathrm{M}$ & 69 & 58 & 71 & 58 \\
\hline
\end{tabular}

values were not alarming in any case. This cytotoxicity can be explained by the higher biostability of these analogs. The degradation of the other two compounds (linear and head-to-tail) implies a short contact time with the cells and therefore lower toxicity.

\section{Conclusions}

This work is a good example of the introduction of organic reactions such as Miyaura borylation and Suzuki cross-coupling onresin. Here, we have prepared a distinct kind of bicyclic peptides (bike peptides) by introducing a biaryl staple bridge in its scaffold. This approach has proved to be an interesting tool through which to increase transport across the BBB by passive diffusion, as well as to enhance serum stability without causing cytotoxicity.

This approach paves the way to introducing the biaryl motifs to other peptides and then improving their permeability and protease-resistance.

\section{Acknowledgements}

This work was supported by MINECO-FEDER (BIO2016-75327-R) and the Generalitat de Catalunya (XRB and 2014-SGR-521). Júlia Garcia was supported by an FPU Grant (AP2012-6464). IRB Barcelona is the recipient of a Severo Ochoa Award of Excellence from MINECO.

\section{References}

1 Feliu L, Planas M. Cyclic peptides containing biaryl and biaryl ether linkages. Int. J. Pept. Res. Ther. 2005; 11: 53.

2 Afonso A, Rosés C, Planas M, Feliu L. Biaryl peptides from 4iodophenylalanine by solid-phase borylation and Suzuki-Miyaura cross-coupling. Eur. J. Org. Chem. 2010; 8: 1461. 
3 Afonso A, Feliu L, Planas M. Solid-phase synthesis of biaryl cyclic peptides by borylation and microwave-assisted intramolecular SuzukiMiyaura reaction. Tetrahedron 2011; 67: 2238.

4 Cerezo V, Amblard M, Martinez J, Verdié P, Planas M, Feliu L. Solid-phase synthesis of 5-arylhistidines via a microwave-assisted Suzuki-Miyaura cross-coupling. Tetrahedro 2008; 64: 10538.

5 Doan N, Bourgaults S, Létourneau M, Fournier AJ. Effectiveness of the Suzuki-Miyaura cross-coupling reaction for solid-phase peptide modification. Com. Chem. 2008; 10: 44.

6 Haug BE, Stensen W, Svendsen JS. Application of the Suzuki-Miyaura cross-coupling to increase antimicrobial potency generates promising novel antibacterials. Bioorg. Med. Chem. Lett. 2007; 17: 2361.

7 Teixidó M, Zurita E, Malakoutikhah M, Tarragó T, Giralt E. Diketopiperazines as a tool for the study of transport across the bloodbrain barrier (BBB) and their potential use as BBB-shuttles. JACS 2007; 129: 11802.

8 Chatterjee J, Rechenmacher F, Kessler H. N-methylation of peptides and proteins: an important element for modulating biological functions. Angew. Chem. Int. Ed. 2013; 52: 254.

9 Prades R, Oller-Salvia B, Schwarzmaier SM, Selva J, Moros M, Balbi M, Grazú V, de la Fuente JM, Egea G, Plesnila N, Teixidó M, Giralt E. Applying the retro-enantio approach to obtain a peptide capable of overcoming the blood-brain barrier. Angew. Chem. Int. Ed. 2015; 54: 3967.

10 Oller-Salvia B, Sánchez-Navarro M, Ciudad S, Guiu M, Arranz-Gibert P, Garcia C, Gomis RR, Cecchelli R, García J, Giralt E, Teixidó M. MiniAp-4: a venom-inspired peptidomimetic for brain delivery. Angew. Chem. Int. Ed. 2016; 55: 572.

11 Pelay-Gimeno M, Glas A, Koch O, Grossman TN. Structure-based design of inhibitors of protein-protein interactions: mimicking peptide binding epitopes. Angew. Chem. Int. Ed. 2015; 54: 8896.

12 Chang YS, Graves B, Guerlavais V, Tovar C, Packman K, Him K, Olson KA Kesavan K, Gangurde P, Mukherjee A, Baker T, Darlak K, Elkin C, Filipovic Z, Qureshi FZ, Cai H, Berry P, Feyfant E, Shi XE, Annis DA Manning AM, Fotouhi N, Nash H, Vassilev LT, Sawyer TK. Stapled $\alpha-$ helical peptide drug development: a potent dual inhibitor of MDM2 and MDMX for p53-dependent cancer therapy. PNAS 2013; 110: , E3445.

13 Verdine GL, Hilinski GJ. All hydrocarbon stapled peptides as synthetic cell-accessible mini-proteins. Drug Discov. Today Technol. 2012; 9: , e41.

14 Isidro-Llobet A, Álvarez M, Albericio F. Chem. Rev. 2009; 109: 2455.

15 Madder A, Farcy N, Hoster NGC, De Muynck H, De Clercq P, Barry J, Davis AP. Eur. J. Org. Chem. 1999; 11: 2787.

16 Christensen AT. Acta. Chem. Scand. Series B. 1979; B33: 763.

17 Spengler J, Jiménez JC, Burger K, Giralt E, Albericio F. Abbreviated nomenclature for cyclic and branched homo- and hetero-detic peptides. J. Peptide Res. 2005; 65: 550.

18 Isidro-Llobet A, Guasch-Camell J, Álvarez M, Albericio F. pNitrobenzyloxycarbonyl (pNZ) as a temporary $\mathrm{N} \alpha$-protecting group in orthogonal solid-phase peptide synthesis - avoiding diketopiperazine and aspartimide formation. Eur. J. Org. Chem. 2005; 3031.

19 de Waterbeemd HV, Camenish G, Folkers G, Chretien JR, Raevsky OA. Estimation of blood-brain barrier crossing of drugs using moleculars size and shape, and H-bonding descriptors. J. Drug Target. 1998; 6: 151.

20 Kelder J, Grootenhuis PD, Bayada DM, Delbressine LD, Ploemen JP. Polar molecular surface as a dominating determinant for oral absorption and brain penetration of drugs. Pharm. Res. 1999; 16: 1514.
21 Doan KMM, Humpreys JE, Webster LO, Wring SA, Shampire L, Serabjit-Singh CJ, Adkinson KK, Polli JW. Passive permeability and Pglycoprotein-mediate efflux differentiate central nervous system (CNS) and non-CNS marketed drugs. J. Pharmacol. Exp. Ther. 2002; 303: 1029.

22 Albericio F, Granier C, Labbé-Juillé M, Seagar F, Couraud F, van Rietschoten J. Solid phase synthesis and hplc purification of the protected 1-12 sequence of apamin for rapid synthesis of apamin analogues differing in the c-terminal region. Tetrahedron 1984; 40: 4313.

23 Guillier F, Orain D, Bradley M. Linkers and cleavage strategies in solidphase organic synthesis and combinatorial chemistry. Chem. Rev. 2000; 100: 2091.

24 Montalbetti CAGN, Falque V. Amide bond formation and peptide coupling. Tetrahedron 2005; 61: 10827.

25 Amblard M, Fehrentza J, Martínez J, Subra G. Methods in Molecular Q12 Biology, 298. J.M. Humana Press Inc.: New Jersey, 2005.

26 Tsuji J. Palladium Reagents and Catalysts Innovations in Organic Q13 Synthesis, 108. Wiley: Chichester, 1995.

27 de Boer AG, Gaillard PJ. Drug targeting to the brain. Annu. Rev. Pharmacol. Toxicol. 2007; 47: 323-355.

28 Pardridge WM. Blood-brain barrier delivery. Drug Discov. Today 2007; 12: 54-61.

29 Temsamani J, Scherrmann JM, Rees AR, Kaczorek M. Brain drug delivery technologies: novel approaches for transporting therapeutics. Pharm. Sci. Technol. Today 2000; 3: 155.

30 Witt KA, Gillespie TJ, Huber JD, Egleton RD, Davis TP. Peptide drug modifications to enhance bioavailability and blood-brain barrier permeability. Peptides 2001; 22: 2329.

31 Alavijeh MS, Chishty M, Qaiser MZ, Palmer AM. Drug metabolism and pharmacokinetics, the blood-brain barrier and central nervous system drug discovery. Neurotherapeutics 2005; 2: 554.

32 Egleton RD, Davis TP. Bioavailability and transport of peptides and peptide drugs into the brain. Peptides 1997; 18: 1431.

33 Kansy M, Senner F, Gubernator K. Physicochemical high throughput screening: parallel artificial membrane permeation assay in the description of passive absorption processes. J. Med. Chem. 1998; 41: 1007.

34 Di L, Kerns EH, Fan K, McConnell OJ, Carter GT. High throughput artificial membrane permeability assay for blood-brain barrier. Eur. J. Med. Chem. 2003; 38: 223.

35 Malakoutikhah M, Teixidó M, Giralt E. Toward an optimal-blood brain barrier shuttle by synthesis and evaluation of peptide libraries. J. Med. Chem. 2008; 51: 4881.

36 Weinstock MT, Nicholas Francis J, Redman JS, Kay MS. Protease-resistant peptide design - empowering nature's fragile warriors against HIV. Biopolymers 2012; 98: 431.

37 Patch JA, Barron AE. Mimicry of bioactive peptides via non-natural, sequence-specific peptidomimetics oligomers. Curr. Opin. Chem. Biol. 2002; 6: 872 .

38 Goodman CM, Choi S, Shandler S, DeGrado WF. Foldamers as versatile frameworks for the design and evaluation of function. Nat. Chem. Biol. 2007; 3: 252.

39 Hill DJ, Mio MJ, Prince RB, Hughes TS, Moore JS. A field guide to foldamers. Chem. Rev. 2001; 101: 3893.

40 Stevenson CL. Advances in peptide pharmaceuticals. Curr. Pharm. Biotechnol. 2009; 10: 122. 


\section{Special Issue Article}

Bike peptides: a ride through the membrane

Júlia García-Pindado, Soledad Royo, Meritxell Teixidó and Ernest Giralt

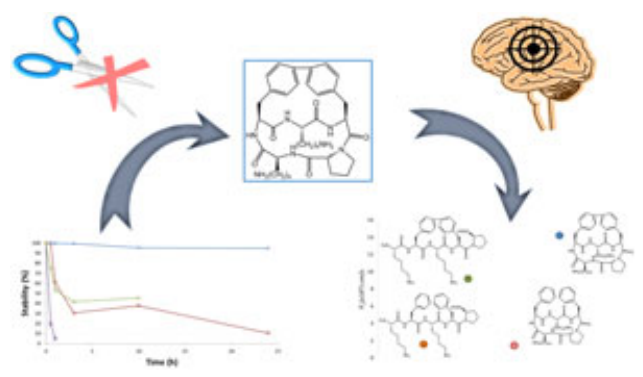




\section{Author Query Form}

\section{Journal: Journal of Peptide Science}

\section{Article: psc_2993}

Dear Author,

During the copyediting of your paper, the following queries arose. Please respond to these by annotating your proofs with the necessary changes/additions.

- If you intend to annotate your proof electronically, please refer to the E-annotation guidelines.

- If you intend to annotate your proof by means of hard-copy mark-up, please use the standard proofing marks. If manually writing corrections on your proof and returning it by fax, do not write too close to the edge of the paper. Please remember that illegible mark-ups may delay publication.

Whether you opt for hard-copy or electronic annotation of your proofs, we recommend that you provide additional clarification of answers to queries by entering your answers on the query sheet, in addition to the text mark-up.

\begin{tabular}{|c|l|c|}
\hline Query No. & & Query \\
\hline Q1 & $\begin{array}{l}\text { AUTHOR: ORCID ID [0000-0001-8381-1797] does not return a valid ORCID profile } \\
\text { when checked against the ORCID registry. Please provide the correct ORCID ID. }\end{array}$ & \\
\hline Q2 & AUTHOR: Please check that authors and their affiliations are correct. & \\
\hline Q3 & $\begin{array}{l}\text { AUTHOR: Please supply a graphical table of contents entry with no more than 80 words } \\
\text { or 3 sentences of text summarising the key findings presented in the paper and a figure that } \\
\text { best represents the scope of the paper. }\end{array}$ & \\
\hline Q4 & AUTHOR: Please check if section headings are presented correctly. & \\
\hline Q5 & $\begin{array}{l}\text { AUTHOR: “Ultra performance liquid chromatography.” Is this the correct definition for } \\
\text { UPLC? Please change if this is incorrect. }\end{array}$ & \\
\hline Q6 & AUTHOR: Please define TIS if this is an abbreviation/acronym. & \\
\hline Q7 & AUTHOR: Please define MTBE if this is an abbreviation/acronym. & \\
\hline Q8 & AUTHOR: Please define DIPCDI if this is an abbreviation/acronym. & \\
\hline Q9 & AUTHOR: Please define HBSS if this is an abbreviation/acronym. & \\
\hline Q10 & AUTHOR: Please define DMEM if this is an abbreviation/acronym. & \\
\hline Q11 & $\begin{array}{l}\text { AUTHOR: “The ability of these peptides to cross the BBB is shown in Table 1.” This } \\
\text { sentence has been reworded for clarity. Please check and confirm if correct. }\end{array}$ & \\
\hline Q12 & AUTHOR: Please provide the page range for this chapter in Reference. & \\
\hline Q13 & AUTHOR: Please provide the page range for this chapter in Reference. & \\
\hline
\end{tabular}


Required software to e-Annotate PDFs: Adobe Acrobat Professional or Adobe Reader (version 7.0 or above). (Note that this document uses screenshots from Adobe Reader $\mathrm{X}$ )

The latest version of Acrobat Reader can be downloaded for free at: http://get.adobe.com/uk/reader/

Once you have Acrobat Reader open on your computer, click on the Comment tab at the right of the toolbar:

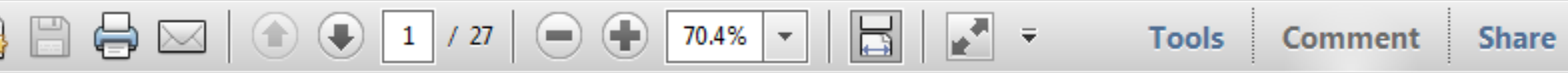

This will open up a panel down the right side of the document. The majority of tools you will use for annotating your proof will be in the Annotations section, pictured opposite. We've picked out some of these tools below:

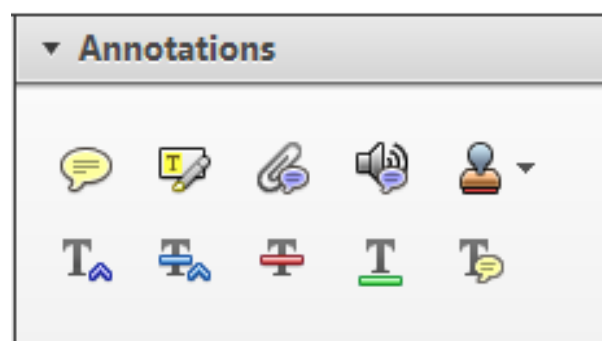

1. Replace (Ins) Tool - for replacing text.

Strikes a line through text and opens up a text box where replacement text can be entered.

How to use it

- Highlight a word or sentence.

- Click on the Replace (Ins) icon in the Annotations section.

- Type the replacement text into the blue box that appears.

Idard tramework for the analysis of $\mathrm{m}$ icy-Nevertheless, it also led to exog،

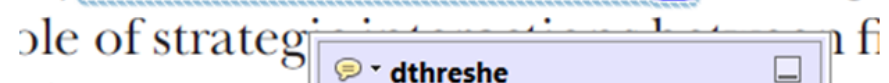
aber of comp 08/06/2011 15:58:17 is that the s1 nain compo: be level, are exc nc

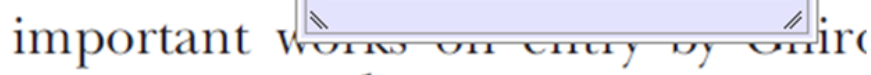
M heneferth) ${ }^{1}$ we anen the "hlarl $\mathrm{l}$

3. Add note to text Tool - for highlighting a section to be changed to bold or italic.

T Highlights text in yellow and opens up a text box where comments can be entered.

\section{How to use it}

- Highlight the relevant section of text.

- Click on the Add note to text icon in the Annotations section.

- Type instruction on what should be changed regarding the text into the yellow box that appears.

namic responses of mark ups ent with the VAR evidence

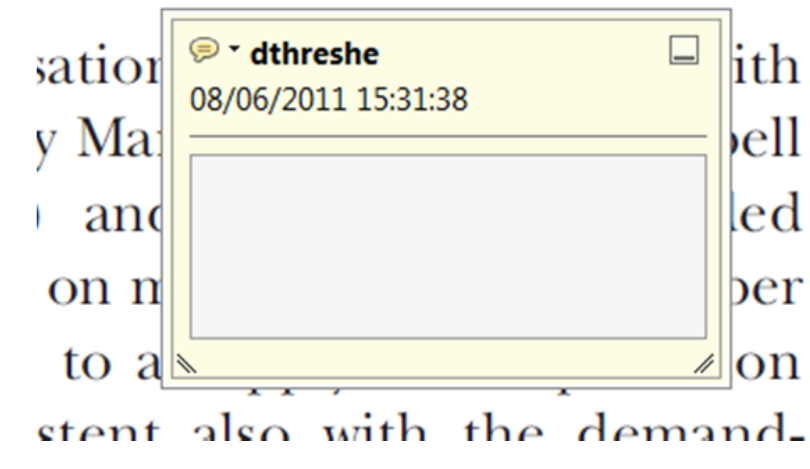

2. Strikethrough (Del) Tool - for deleting text.

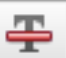

Strikes a red line through text that is to be deleted.

How to use it

- Highlight a word or sentence.

- Click on the Strikethrough (Del) icon in the Annotations section.

there is no room tor extra prohts al c ups are zero and the number of ret) values are not determined by Blanchard and Kiyotaki (1987), sfect competition in general equilil ts of aggregate demand and supply lassical framework assuming monol eph on evorenous number of firme

4. Add sticky note Tool - for making notes at specific points in the text.

Marks a point in the proof where a comment needs to be highlighted.

How to use it

- Click on the Add sticky note icon in the Annotations section.

- Click at the point in the proof where the comment should be inserted.

- Type the comment into the yellow box that appears.

iaisu airu suppiy sirucks. hivsl ui

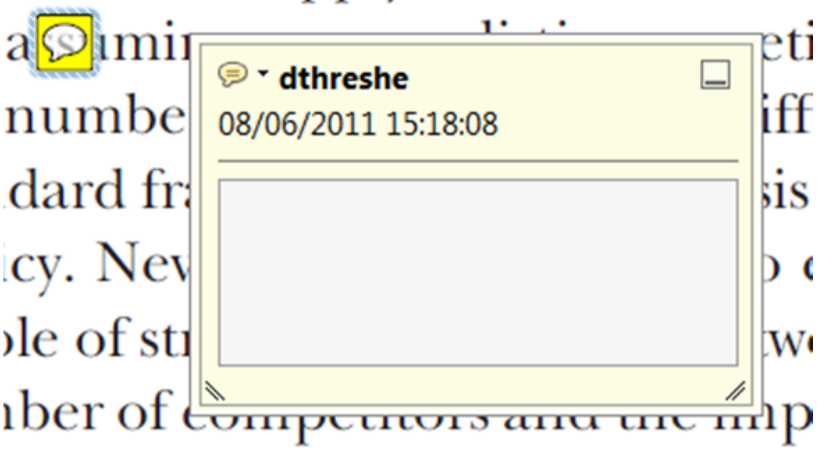

is that the structure of the secto. 
5. Attach File Tool - for inserting large amounts of text or replacement figures.

Inserts an icon linking to the attached file in the appropriate pace in the text.

How to use it

- Click on the Attach File icon in the Annotations section.

- Click on the proof to where you'd like the attached file to be linked.

- Select the file to be attached from your computer or network.

- Select the colour and type of icon that will appear in the proof. Click OK.

E N D

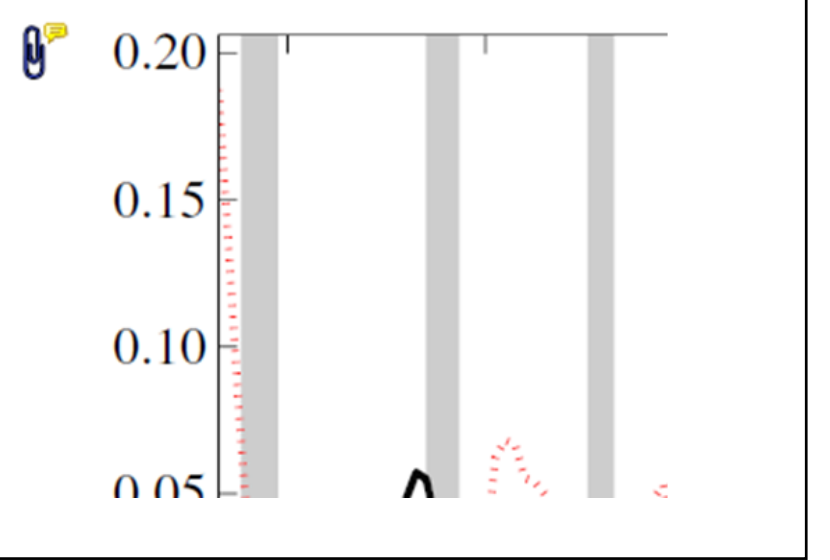

6. Add stamp Tool - for approving a proof if no corrections are required.

- Inserts a selected stamp onto an appropriate place in the proof.

\section{How to use it}

- Click on the Add stamp icon in the Annotations section.

- $\quad$ Select the stamp you want to use. (The Approved stamp is usually available directly in the menu that appears).

- Click on the proof where you'd like the stamp to appear. (Where a proof is to be approved as it is, this would normally be on the first page).

or the business cycie, starting with the on perfect competition, constant ret

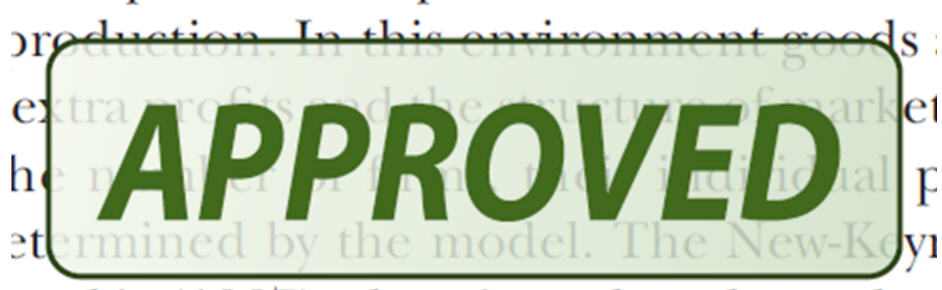
otaki (1987), has introduced produc general equilibrium models with nomin:

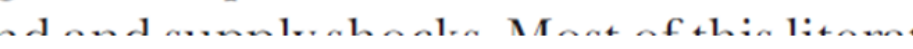

- Drawing Markups

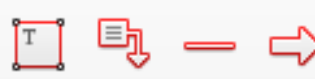

$0 \bigcirc \sqrt{6} \otimes$

\section{How to use it}

- Click on one of the shapes in the Drawing Markups section.

- Click on the proof at the relevant point and draw the selected shape with the cursor.

- To add a comment to the drawn shape, move the cursor over the shape until an arrowhead appears.

- Double click on the shape and type any text in the red box that appears.
7. Drawing Markups Tools - for drawing shapes, lines and freeform annotations on proofs and commenting on these marks.

Allows shapes, lines and freeform annotations to be drawn on proofs and for comment to be made on these marks.

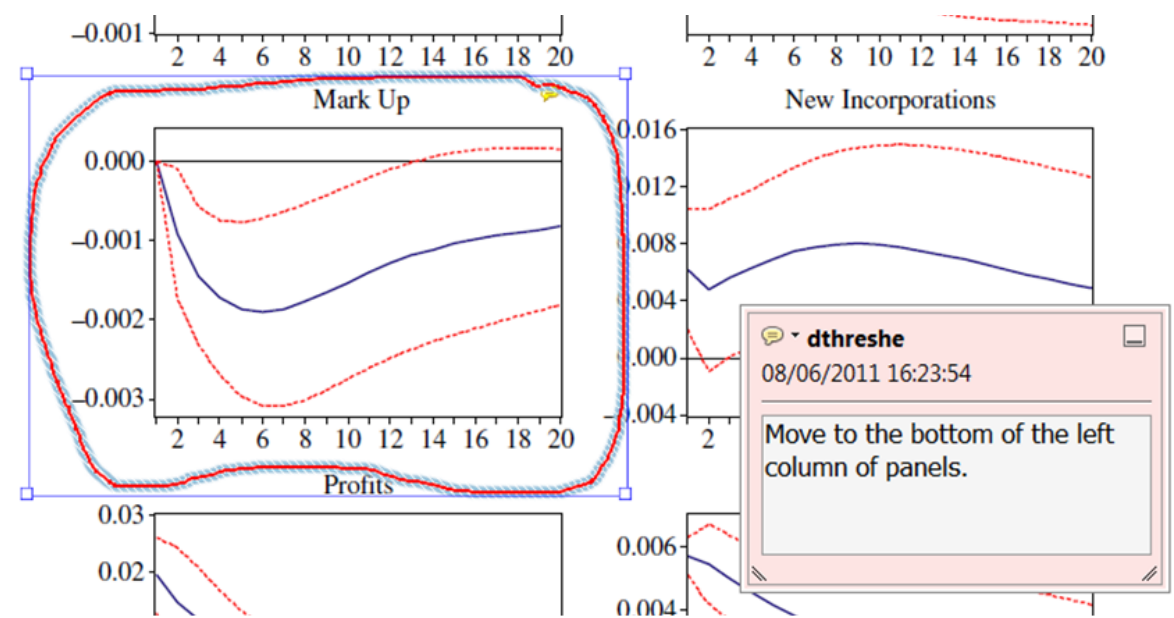

For further information on how to annotate proofs, click on the Help menu to reveal a list of further options:

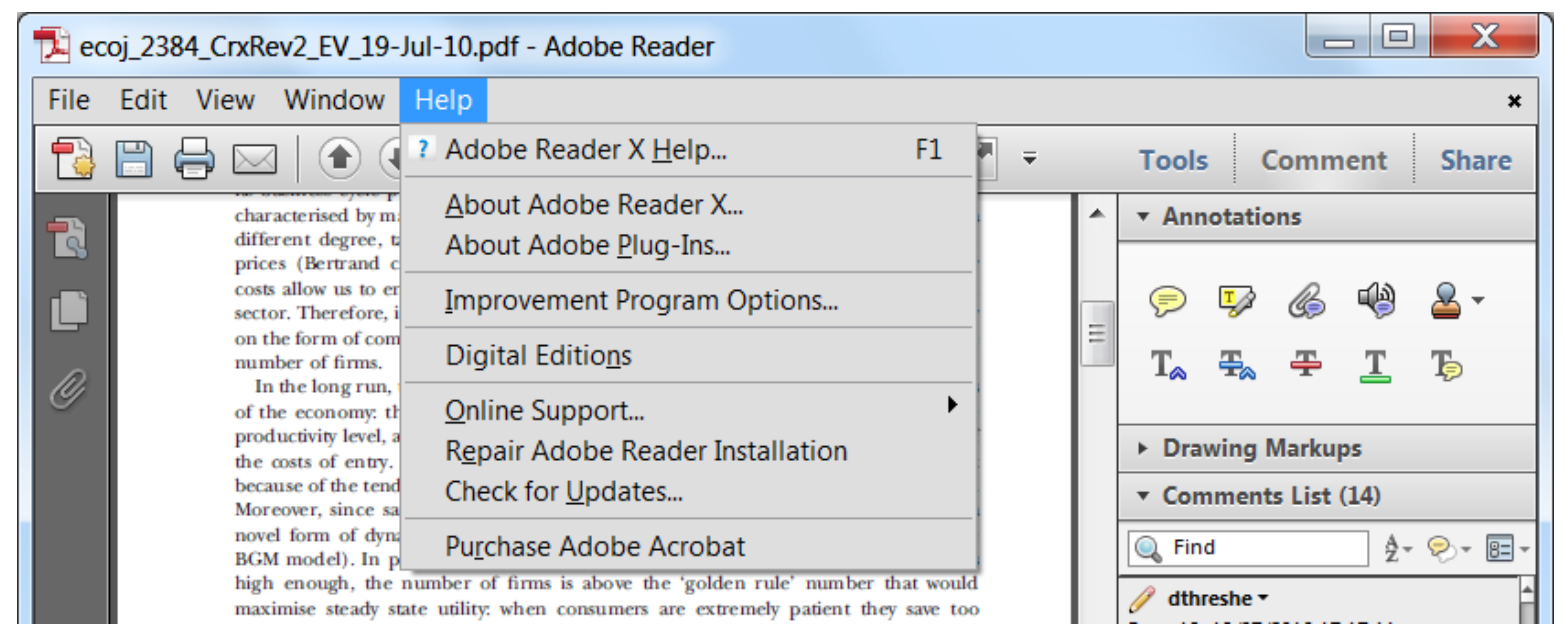

